\title{
Protective Effect of a High Protein Diet against the Toxicity of Some Organophosphorus Compounds in Albino Rats
}

\author{
Ajit K. Chatterjee and Usha Kaveeshwar \\ Defense Research and Development Establishment, Tansen Road, Gwalior 474002, India \\ Received March 19, 1991 Accepted June 10, 1991
}

\begin{abstract}
The present investigation deals with determining the efficacy of a high protein diet (HPD) in combating toxicity in albino rats of some organophosphorus compounds (OPCs) that follow dissimilar metabolic patterns in a living system. As assessed by an increase or decrease in the levels of some biochemical and nutritional parameters, the high protein diet containing $59 \%$ protein seems to have a beneficial effect in alleviating toxicity of low but prolonged doses of OPCs over the standard diet (SD) containing $19 \%$ protein. OPCs undergoing direct detoxication in a living system like diisopropyl phosphoro-fluoridate (DFP) appear to be more susceptible to HPD than those undergoing biotoxication like EPN (O-ethyl O-p-nitrophenyl phenylphosphonothioate) and malathion (S-(1,2-dicarbethoxyethyl) O,O-dimethyldithiophosphate).
\end{abstract}

Nutritional factors play an important rolc in the metabolism and pharmacotoxicological activities of various drugs and xenobiotics (1). A dietary reduction in either quality or quantity of protein causes a depression of hepatic microsomal mixed function oxidase activities. According to Boyd (2), these results have a direct application to the toxicity of drugs and chemical agents in persons whose dietary protein is low. Kato et al. (3) reported decreased microsomal drug metabolizing enzymes in rats on a protein-deficient diet. The functions of these enzymes are to metabolize and thereby detoxify any xenobiotic (4). The original reports of increased toxicity of drugs during protein deficiency were submitted by Drill in 1952 (5).

Chemical toxicity can be divided into two categories: parent compound-induced toxicity and metabolite mediated toxicity. The relationship of biotransformation to toxicity in the former category is rather simple as biotransformation means detoxication. In the lat- ter case, on the other hand, the relationship is more complicated. Biotransformation may lead to biotoxication or bioactivation. The toxicities in vivo of foreign compounds administered to protein-deficient animals apparently depend on whether the principal reaction step represents intoxication or detoxication. For a chemical that gets bioactivated, the test animal is exposed to the stress of a more toxic metabolite for a longer period when on a high protein dict (HPD).

An attempt has been made in the present investigation to study the efficacy of HPD in alleviating toxic effects of some organophosphorus compounds (OPCs) that are either similar, vis a vis chemical structure and toxicity, to some chemical warfare agents (6) like diisopropyl phosphorofluoridate (DFP) or are insecticides of low toxicity like malathion (S-(1.2-dicarbethoxyethyl) O.O-dimethyldithiophosphate) or EPN (O-ethyl O-p-nitrophenyl phenylphosphonothioate).

DFP is a structural analogue of the nerve 
gas Sarin (methyl isopropyl phosphonofluoridate), and hence expected to behave as sarin because of the close interrelationship between chemical constitution and physiological activity in certain compounds (7).

Two other pesticides of low toxicity, malathion and EPN, were included in the present study as they follow a different metabolic pattern than DFP in a living system: they become biotoxicated first, instead of undergoing direct detoxication (6).

The biochemical studies carried out on male albino rats included determination of serum cholinesterase (ChE) and aminotransferase activities (SGOT and SGPT), liver glycogen. serum albumin/globulin ( $\mathrm{A} / \mathrm{G})$ ratio and liver/body wt. index. It is well-established in the literature that under conditions of toxicity, serum ChE activity, liver glycogen levels and $A / G$ ratios are lowered and serum aminotransferase activity and liver/body wt. indices are increased with respect to their corresponding control values.

The nutritional aspect, dealing with studies on growth rates in albino rats under combined effects of low but prolonged doses of OPCs (DFP, EPN and malathion), taken separately, and respective standard (SD) and modified dicts like low-protein diet (LPD) and HPD were communicated earlier $(8,9)$.

From our earlier studies $(8,9)$, elevations in growth rates under HPD alone and also in all the three OPC-treated groups under HPD could be found as compared to the SD control. In the case of DFP combined with HPD (containing $59 \%$ protein), the elevation in growth rate was $76.4 \%$; for EPN, $6.1 \%$; and for malathion, $51.8 \%$. Whereas in the case of DFP combined with SD (containing $19 \%$ protein), the elevation in growth rate was $22.7 \%$, for $\mathrm{EPN}$, the depression in growth rate was $35.5 \%$ and for malathion, the depression in growth rate was $50.9 \%$. For the HPD control, the percent elevation in growth rate was 134.3 as compared to SD. Thus the beneficial effect of HPD was obvious, and the capacity of alleviation of toxicity increased with the increase in protein content. The protective action was most pronounced in the case of DFP and least in the case of EPN. The difference in the mode of biotransformations of the two compounds was probably the cause.

The diets on which the animals were kept were assessed as suitable, if on administration of a daily low dose (approx. $5 \% \mathrm{LD}_{50}$ ) of the toxic OPCs for 20 days, the toxic effects were not observed.

In the present study, inhibition of serum ChE activity, rise in serum aminotransferase(s) activity, depletion of liver glycogen, lowering of serum $A / G$ ratio and rise in liver/body wt. indices compared to the controls were taken as standards for the manifestation of toxicity.

\section{MATERIALS AND METHODS}

Male albino rats of the Wistar strain (body wt. $130 \pm 15 \mathrm{~g}$ ) were divided into eight groups of eight animals each. Groups I and V served as controls for their respective dietary categories, $\mathrm{A}$ and $\mathrm{B}$ being given SD containing $19 \%$ protein and isocaloric HPD containing $59 \%$ protein, respectively. The composition of the two isocaloric diets are as described by Purshottam \& Kaveeshwar (10) in Table 1.

These two groups received the same quantity of diluents as the experimental animals in various groups that were used for the dilution of OPCs.

Groups II, III and IV were kept on SD and daily s.c. doses of DFP $(0.025 \mathrm{mg} / \mathrm{rat} /$ day $)$, EPN $(0.3 \mathrm{mg} / \mathrm{rat} / \mathrm{day})$ and malathion (10.3 $\mathrm{mg} / \mathrm{rat} /$ day), respectively, for 20 days, which was equivalent to $5 \%$ of their respective $\mathrm{LD}_{50}$ values.

Groups VI, VII and VIII received in addition to the HPD described above, daily doses of DFP, EPN or malathion for the same period and in the same doses.

The dilutions of OPCs were made in distilled water with propylene glycol $(1 \mathrm{ml})$ bcing initially added in each. The quantity of food given was $17 \mathrm{~g} / \mathrm{rat} /$ day, which had no left-over as studied by separate experiments.

On the 21st day, the overnight fasted rats 
Table 1. Composition of different diets (dietary constituents in $\mathrm{g} / 100 \mathrm{~g}$ diet)

\begin{tabular}{|c|c|c|}
\hline \multirow[t]{2}{*}{ Constituents } & \multicolumn{2}{|c|}{ Diet } \\
\hline & standard & high protein \\
\hline Sucrose & 60 & 20 \\
\hline Cascin & 19 & 59 \\
\hline Dalda * & 10 & 10 \\
\hline Cod liver oil & 1 & 1 \\
\hline Yeast powder & 2 & 2 \\
\hline Tetra cycline & 0.01 & 0.01 \\
\hline Salt mixture ${ }^{* *}$ & 2 & 2 \\
\hline Cellulose & 6 & 6 \\
\hline $\mathrm{Kcal} / 100 \mathrm{~g}$ & 415 & 415 \\
\hline $\mathrm{g} / \mathrm{day} / \mathrm{rat}$ & 17 & 17 \\
\hline Kcal intake/rat/day *** & 70.5 & 70.5 \\
\hline
\end{tabular}

* Dalda is the commercial name of common edible hydrogenated vegetable oils mainly composed of ground nut and repressed oils. ${ }^{* *}$ USP 17 salt mixture. ${ }^{* * *}$ The caloric intake was calculated assuming that the animals consumed all the food given to them.

(for reasons of attaining a steady state of body metabolism) were separately weighed and anesthetized with ether; and samples of blood (approx. $3 \mathrm{ml}$ ) were collected from the orbital sinus (11) into tubes and then centrifuged to obtain the serum. The whole liver from each animal was taken out, soaked in folds of filter paper and weighed for the determination of liver/body wt. indices. A weighed portion (approx. $1 \mathrm{~g}$ ) of each liver sample was dipped into tubes containing $30 \% \mathrm{KOH}(6 \mathrm{ml})$ for the estimation of glycogen. The serum samples were used for the analyses of ChE, SGOT, SGPT and $A / G$ ratios.

Assay of ChE based on the disapperance of acetylcholine $(\mathrm{ACh})$ determined as the ferric aldoxime complex (12) was performed as reported by Augustinson (13). The aminotransferase(s) activities in serum was measured by the Reitman and Frankel method (14). Glycogen was isolated by Hawk's procedure (15) and estimated as glucose (16). $\mathrm{A} / \mathrm{G}$ ratios were determined after separation of albumin from the total globulins in the serum by low voltage paper electrophoresis at 100 volts for $16 \mathrm{hr}$ using barbitone buffer ( $\mathrm{pH} \mathrm{8.6)}$.

\section{RESULTS}

Table 2 shows that under SD alone, there is statistically no change in the serum ChE activity from that when HPD was taken alone (c.f. group I versus group V). However, a slightly higher ChE activity is observed in the HPDtreated group.

In Table 2, category A (SD), under the combined effects of SD and DFP/EPN, taken separately, highly significant $(\mathrm{P}<0.001)$ inhibitions in serum ChE activities could be seen (c.f. groups II and III versus group I). In contrast, in category B (HPD), under HPD either alone or in combination with DFP/ $\mathrm{EPN} /$ malathion, the $\mathrm{ChE}$ activities remained unaffected (c.f. groups VI, VII and VIII versus group V).

If the levels of $\mathrm{ChE}$ in categories $\mathrm{B}$ and $\mathrm{A}$ in separate DFP. EPN and malathion treated groups are compared, their levels will be found to be significantly more $(\mathrm{P}<0.001, \mathrm{P}$ $<0.001$ and $\mathrm{P}<0.05$ ) in category $\mathrm{B}$ (HPD treated group) than their corresponding values in category A (under SD).

Changes in activities of serum aminotransferase(s) are also recorded in Table 2. Compared to the SD group I in category A, SGOT and SGPT levels under HPD alone in group $V$ in category $\mathrm{B}$ are significantly lower $(\mathrm{P}<$ 0.001 and $\mathrm{P}<0.05$ ).

Under the combined action of $\mathrm{SD}$ and DFP/EPN, there were significant decreases ( $P$ $<0.001$ and $\mathrm{P}<0.05$ ) of SGPT levels (c.f. groups II and III versus group I). However, for malathion under similar conditions, there was a significant increase $(\mathrm{P}<0.001$ ) in SGPT level (c.f. group IV versus group I).

Under the combined effects of HPD and various OPCs, there were no observable changes in either SGOT or SGPT levels (c.f. groups VI, VII and VIII versus group V).

Liver glycogen values are also shown in Table 2. The control value of glycogen under HPD was significantly higher than that under SD (c.f. group V versus group I). Also, the values of glycogen under the combined actions of HPD and various OPCs, separately taken. 


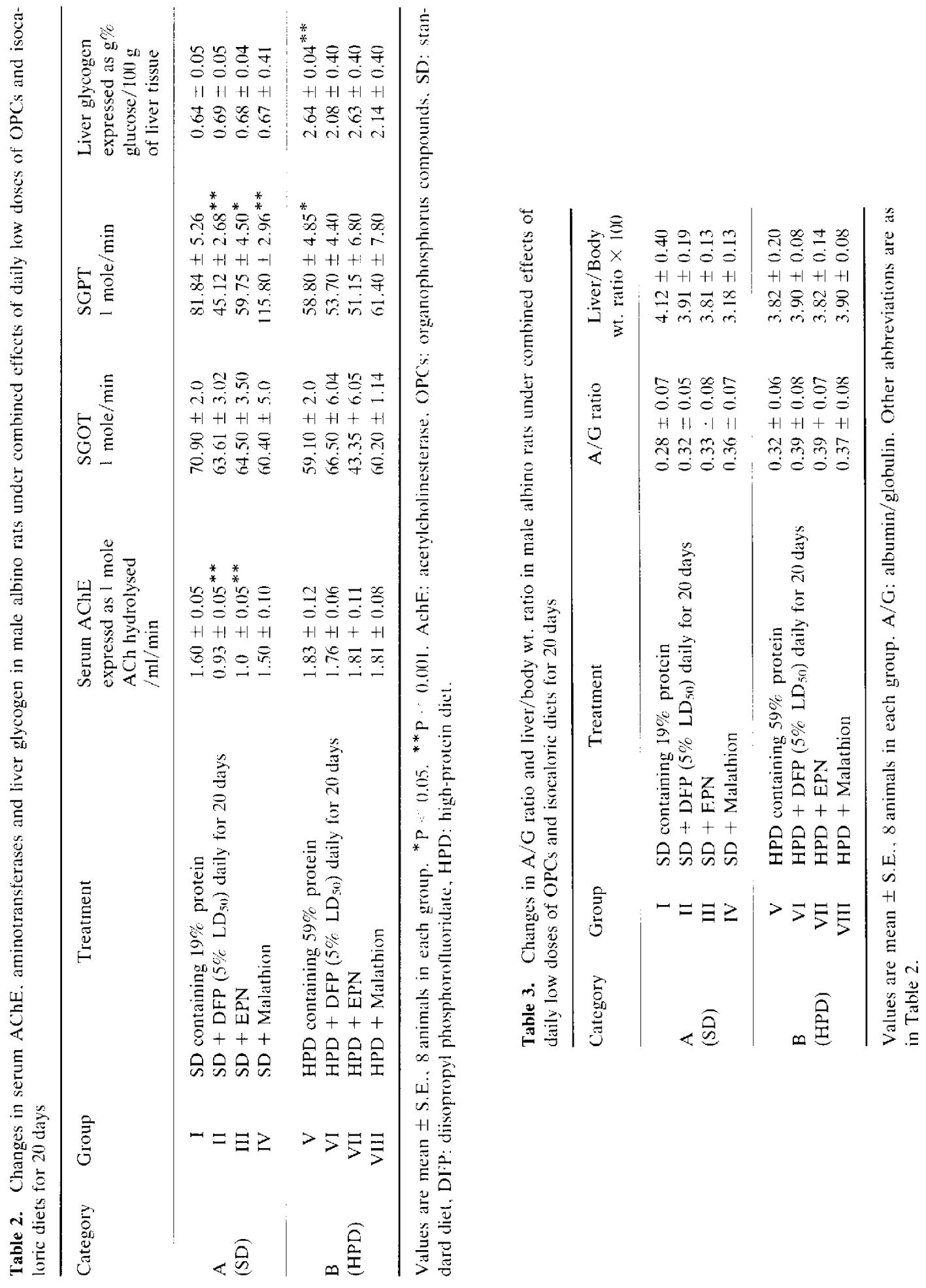


were significantly higher than their corresponding values under SD.

Table 3 indicated no changes in $\mathrm{A} / \mathrm{G}$ ratios and liver/body wt. indices in various groups both under combined effects of SD or HPD and individual OPCs.

\section{DISCUSSION}

The primary action of OPCs are to inhibit AChE activity leading to accumulation of $\mathrm{ACh}$ in cholinergic nerve endings, which in turn is responsible for toxic effects (17) due to continuous stimulation of cholinergic fibers through out the central and peripheral nervous system.

Highly significant lowerings of serum $\mathrm{ChE}$ levels could be seen in the case of DFP/EPN, taken separately, along with $\mathrm{SD}$ indicating non-alleviation of toxicity under $\mathrm{SD}$, of course with the exception of the $\mathrm{SD} /$ malathion combination. However, on changing over to HPD, $\mathrm{ChE}$ activities were not lowered by any of the three OPCs, probably due to rapid detoxication of OPCs by microsomal drug metabolizing enzymes formed in the liver under HPD. Another possiblity could be that in the 20-day feeding experiments with a high protein diet, there may be an enhanced de novo synthesis of ChE, which is an enzyme protein, and which can compensate for the irreversibly phosphorylated cnzyme. This shows the efficacy of HPD over SD.

Increase in the levels of serum aminotransferase(s) is an indicator of toxic stress (18). It can be hepatotoxicity, cardiotoxicity and nephrotoxicity. Assessed with respect to the increase in the levels of these enzymes, HPD seems to be a better diet than SD as there is no increase in these enzyme levels under the combined effects HPD/OPCs. Again, the cause may be due to rapid detoxication of toxic OPCs under HPD. It may be noticed under the $\mathrm{SD} /$ malathion combination, there is a significant increase in SGPT activity indicating non-alleviation of toxicity by SD. Also, under HPD, the control values are significantly lower compared to the SD control, indicating les- ser toxicity of HPD.

Additional synthesis of liver glycogen could be seen under HPD alone. Also, under HPD/OPCs combinations, the glycogen values remained at comparatively higher levels than their corresponding levels under SD. This shows the beneficial effect of HPD over SD as extra glycogen means extra stored energy in a living system.

Table 3 shows no changes in $A / G$ ratios and liver/body wt. indices in various groups both under $\mathrm{SD}$ and $\mathrm{HPD}$. $\mathrm{A} / \mathrm{G}$ ratios are lowered under hepatotoxicity (19) and liver/body wt. indices increase under formation of fatty liver. Considering all the parameters together, HPD seems to be superior to SD in alleviating the toxicity of OPCs.

The mode of action of protein in the diet seems to be two fold. First, it helps in the extra synthesis of $\mathrm{ChE}$ in a living system which in turn counteracts the toxicity caused by inhibition of native $\mathrm{ChE}$. The enzyme $\mathrm{ChE}$ is a protein and dietary deficiency of protein can result in lower $\mathrm{ChE}$ activity in liver microsomes and serum of rats (20). Casterline et al. (21) observed that Che inhibition of some OPCs like parathion and banol is more at lower dietary levels of cascin than at higher levels. This proves that the toxicity of these enzyme inhibitors is greater at lower dietary protein levels. Caldara (22) observed that a protein diet protected rats from acute poisoning by $98 \%$ parathion $(500 \mathrm{mg} / \mathrm{kg}, \mathrm{s.c}$.). The morphological changes in liver tissue and decreases in glycogen and nucleic acid content were lcss severe in rats given a high protein diet than in those given a diet with a normal protein content.

On the other side, protein in the diet increases the over-all concentration of cyt-P-450 linked monooxygenases (drug metabolizing enzymes or mixed function oxidases) that are predominantly present in liver microsomes (4). The direct role of dictary protein in increasing the concentration of cyt-P-450 linked monooxygenases is not known. However, Kato (3) reported decreased microsomal drug metabolizing enzymes in rats on a protein-deficient diet, 
thereby proving the other role of protein.

The microsomal drug metabolising enzyme plays a very important part in chemical toxicity and can detoxify (and also activate in some cases) any xenobiotic (4). The enzymes in the liver have been shown to be susceptible to the influences of environmental factors $(23,24)$ out of which dietary factors are of prime importance.

\section{Acknowledgments}

The authors thank Dr. R.V. Swamy, Director, Defense Research and Development Establishment, Gwalior, and Prof. K.M. Rao, Head of the Entomology and Biochemistry Division, for keen interest in this work.

\section{REFERENCES}

I Campbell, T.C. and Hayes, J.R.: The effect of quantity and quality of dietary protein in drug metabolism. Fed. Am. Soc. Exp. Biol. 35. 24702474 (1976)

2 Boyd, E.M.: Diet and drug toxicity. Clin. Toxicol. 2, 423-433 (1969)

3 Kato, R., Chiesara, E. and Vassanelli, P.: Factors influencing induction of hepatic microsomal drug metabolising cnzymes. Biochem. Pharmacol. 11. $211-220(1962)$

4 Sato, A. and Nakazima. T.: Dietary carbohydrates and ethanol induced alteration of the metabolism and toxicity of chemical substances. Nutr. Cancer 6. $121-132(1984)$

5 Drill, V.A.: Hepatotoxic agents. Mechanism of action and dietary interrelationship. Pharmacol. Rcv. 4, 1-42 (1952)

6 Koelle, G.B.: Anticholinesterase agents. In the Pharmacological Basis of Therapeutics, Edited by Goodman, S. and Gilman, A., 5th Edn., p. 451. Macmillan Company, London and Toronto (1975)

7 Mitra, D.P. and Chatterjee, A.K.: Structure activity relationship of various azo derivatives of salicylic acid. Labdev. J. Sci. Tech. India 10-A, 154158 (1972)

8 Chatterjee, A.K and Kaveeshwar, U.: Alleviating effect of high protein diet (HPD) on the toxic effect of organophosphorus (OP) compounds on the growth of rats. Def. Sci. J. 39, $109-[12$ (1989)

9 Chatterjec. A.K.: Comparative evaluation of the alleviating effect of high protein diet (HPD) on the toxic effect of organophosphorus (OP) compounds on the growth of rats. Def. Sci. J. 39,
$201-204(1989)$

10 Purshottam, T. and Kaveeshwar, U.: Effect of diet on dichlorovinyl dimethyl phosphate on toxicity in rats. Aviat. Space Environ. Med. (June) 581-584 (1979)

11 Stone, S.H.: Method of obtaining venus blood from the orbital sinus of the rat or mouse. Science 119, 100-104 (1954)

12 Hestrin, S.: Reaction of acetylcholine and other carboxylic acid derivatives with hydroxylamine and its analytical application. J. Biol. Chem. 180, $249-$ 261 (1949)

13 Augustinson, K.: Assay methods for cholinesterase. In Methods of Biochemical Analysis, Edited by Glick, D.. Vol. 5. p. 44-54. Interscience Publishers Inc., New York (1957)

14 Reitman, F. and Frankel, S.: Determination of glutamic oxalacetic and glutamic pyruvic transaminase. Am. J. Clin. Pathol. 28, 56-63 (1957)

15 Oser, E.: Hawk's Physiological Chemistry, p. 783, McGraw Hill, New York (1964)

16 Dubois, M.. Gilles, K.A., Hamilton, J.K., Rebers, P.A. and Smith, F.: Colorimetric method for determination of sugars and related substances. Anal. Chem. 7, $542-545$ (1961)

17 Koelle. G.B.: Anticholinesterase agents. In the Pharmacological Basis of Therapeutics, Edited by Goodman. S. and Gilman. A., 3rd Edn., p. 441, Macmillan Company, New York (1965)

18 Wootton, I.D.P.: Microanalysis in Medical Biochemistry, p. 109. J.A. Churchill, Ltd., London (1964)

19 Varley, H.: Practical Clinical Biochemistry, p. 260, Arnold Heinemann Publishers (India) Pvt. Ltd., New Delhi (1975)

20 Natoff, T.L.: Organophosphorus pesticides: Pharmacology. In Progress in Medicinal Chemistry 8 , Part I, Edited by Ellis, G.P. and West, G.B., p. 5, Butterworths, London (1976)

21 Casterline, J.L., Jr., Williams, C.H. and Keys. J.E.: Effect of pesticide administration on the esterase activities in serum and tissues of rats fed variable casein diets. Toxicol. Appl. Pharmacol. 14, $266-275$ (1969)

22 Caldara. G.: Morphological study of the liver of rats with organic phosphorus ester poisoning. Arch. Sci. Med. 125, 293 (1969)

23 Conney, A.H.: Pharmacological implications of microsomal enzyme induction. Pharmacol. Rev. 19, 317-366 (1967)

24 Campbell, T.C. and Hayes. J.R.: Role of nutrition in the drug metabolising enzyme system. Pharmacol. Rev. 26, 171-197 (1974) 